\title{
Mass-balance rates derived by mapping internal tephra layers in Mýrdalsjökull and Vatnajökull ice caps, Iceland
}

\author{
Ola BRANDT, ${ }^{1, *}$ Helgi BJÖRNSSON, ${ }^{2}$ Yngvar GJESSING ${ }^{3}$ \\ ${ }^{1}$ The University Centre in Svalbard (UNIS), Box 156, NO-9171 Longyearbyen, Norway \\ E-mail: ola.brandt@npolar.no \\ ${ }^{2}$ Science Institute, University of Iceland, Sturlugata 7, IS-101 Reykjavík, Iceland \\ ${ }^{3}$ Geophysical Institute, University of Bergen, NO-5007 Bergen, Norway
}

\begin{abstract}
Internal tephra layers of known age have been detected by radio-echo soundings within the Mýrdalsjökull and Vatnajökull ice caps in Iceland. Assuming steady state, the estimated strain rates since these isochrones were deposited on the glacier surface have been used to calculate past average specific net balance rates in the accumulation zones along three flowlines on Mýrdalsjökull and one on Vatnajökull. For the period 1918-91 the specific mass-balance rate has been estimated to 4.5 and $3.5 \mathrm{~m} \mathrm{a}^{-1}$ at $1350 \mathrm{~m}$ a.s.I. on the southern and northern slopes of Mýrdalsjökull, respectively. At $1800 \mathrm{~m}$ elevation on the Bárdarbunga ice dome in Vatnajökull, the specific net balance averaged over the last three centuries is estimated to be about $2.1 \mathrm{~m} \mathrm{a}^{-1}$. Given this specific net balance, a revised age-depth timescale is presented for a $\mathbf{4 0 0} \mathrm{m}$ deep ice core recovered in 1972 from Bárdarbunga. The ice at the bottom is estimated to be from AD 1750.
\end{abstract}

\section{INTRODUCTION}

Internal tephra layers have been used to date ice cores and to estimate past specific net balance rates in glaciers and ice caps (Hammer and others, 1978; Steinthórsson, 1978; Karlöf and others, 2000; Thorsteinsson and others, 2003). A single core can give high-resolution data at a specific position, but mapping of tephra layers over large areas can provide information about the spatial variations of the glacier mass balance.

In the Vatnajökull and Mýrdalsjökull ice caps, Iceland, internal tephra layers of known age have been detected by radio-echo soundings. These layers were deposited on the ice-sheet surface during volcanic eruptions and subsequently buried in the accumulation area and deformed during the ice flow. These isochrones provide information on past strain rates, ice movements and spatial distribution of the specific net balance (Nereson and others, 2000; Baldwin and others, 2003).

We apply a steady-state flowline model outlined by Reeh (1989) to derive the specific net balance pattern matching the spatial depth distribution of the internal time markers. Inputs to the model are the ice thickness and the horizontal convergence or divergence along the flowline.

\section{SITE DESCRIPTION AND FIELD DATA}

Mýrdalsjökull and Vatnajökull are situated in the southern part of Iceland (Björnsson, 1980, 1988, 2002; Björnsson and others, 2000). The region has a maritime climate with low summer temperatures and heavy precipitation (ranging from 2500 to $>4200 \mathrm{~mm} \mathrm{a}^{-1}$ (Eythórsson and Sigtryggsson, 1971)). The ice caps are dynamically highly active and they

*Present address: Norwegian Polar Institute, Polarmiljøsenteret, NO-9296 Tromsø, Norway. change rapidly with climate variations (Björnsson, 1980; Jóhannesson and Sigurðsson, 1998; Sigurðsson, 1998). The ice caps are situated in a region of high volcanic activity and the ice is rich with volcanic fallouts that have been used to date the ice (Steinthórsson, 1978; Larsen and others, 1996, 1998).

The two ice caps have been mapped by radio-echo sounding, and digital elevation models have been produced of both the glacier surface and the bedrock (Björnsson, 1988; Björnsson and others, 2000). Internal reflections caused by tephra layers have been mapped. The internal reflections that have been traced to specific volcanic eruptions have been used as internal time markers along selected flowlines. The time marker on Mýrdalsjökull is the tephra layer of the 1918 Katla (Iceland) eruption.

On Vatnajökull, specific net balance measured at stakes in the 1990s has been used as input to the model (Björnsson and others, 1998), together with accurate dating of the uppermost tephra layers (first $120 \mathrm{~m}$ ) of a $400 \mathrm{~m}$ deep core drilled at Bárdarbunga in 1972 (Steinthórsson, 1978). Our model suggests a revised age-depth distribution in the lower part of the core.

\section{METHOD}

The theoretical model used is based on work by Reeh (1989) and Brandt (2001). The notation used in this paper is as far as possible that of Reeh (1989). The model is a steadystate flowline model, taking into account the effect of varying ice thickness and horizontal divergence or convergence along the flow. Given the flowline geometry and the isochrones, we seek, by trial-and-error iteration, the surface net balance pattern that can best reproduce the age-depth distribution. In its current state, the application of the model is limited to the upper part of the ice column where the horizontal ice velocity can be assumed constant with depth. 


\section{CONSERVATION OF MASS, PARTICLE PATH, LAYER THICKNESS, AGE-DEPTH PROFILES AND ISOCHRONES}

For a curvilinear coordinate system, Reeh (1989) writes the solution of the differential continuity equation as:

$$
q(x)=\exp ^{-\int \frac{1}{R(x)} \mathrm{d} x} \int \dot{b}(x) \exp \int \frac{1}{R(x)} \mathrm{d} x \mathrm{~d} x+C,
$$

where $q$ is the flux per unit width, $R$ the radius of curvature of the topographic contour lines intersecting with the flowline, $\dot{b}$ the net balance rate, $x$ the distance along the flowline and $C$ an arbitrary constant determined by boundary conditions that in our case equals zero.

The specific net balance rates along the flowlines have been described as a third-degree polynomial to make calculations feasible and reasonably flexible:

$$
\dot{b}(x)=\alpha_{0}+\alpha_{1} x+\alpha_{2} x^{2}+\alpha_{3} x^{3} .
$$

The constants $\alpha_{0}, \ldots, \alpha_{3}$ are adjusted to describe the specific net balance pattern along the flowline.

Assuming constant divergence or convergence along the flowline, rewriting the radius of curvature as $R(x)=x / m$, where $m=0$, thus corresponds to plane flow and $m=1$ radial flow from a circular dome; and inserting the net balance rate (Equation (2)), the ice flux along the flowline can be expressed as

$$
q(x)=\frac{\alpha_{0} x}{m+1}+\frac{\alpha_{1} x^{2}}{m+2}+\frac{\alpha_{2} x^{3}}{m+3}+\frac{\alpha_{3} x^{4}}{m+4} .
$$

In a steady-state model a particle path describes a flowline. A particle deposited at the surface position $x_{1}$ in the accumulation zone is at time $t=t_{2}$ at the position $x_{2}$ and at height $\tilde{h}$ above the bed. Following Reeh (1989), we use non-dimensional vertical and height coordinates defined as $\tilde{z}=(z-B(x)) / H(x)$ and $\tilde{h}=h / H_{2}$, respectively, where $B(x)$ and $H(x)$ are the height of the lower surface and the ice thickness, respectively, and $z$ and $h$ are the vertical height and the height above the glacier sole, respectively. Based on mass conservation for a flow tube in a curvilinear coordinate system, particle paths within the accumulation zone can be expressed (Reeh, 1989):

$$
\psi(\tilde{h})=\frac{q\left(x_{1}\right)}{q\left(x_{2}\right)} \exp ^{\int_{x_{2}}^{x_{1}} \frac{1}{R} d x} .
$$

Solving Equation (4) with respect to $x_{1}=x_{1}\left(x_{2}, \tilde{h}\right)$, the original horizontal deposition position can be found of a particle now at height $\tilde{h}$ and position $x_{2}$. The original surface position is thus dictated by the ice flux $q$ and the degree of convergence and divergence $R$, as well as by a shape function: $\psi(\tilde{z})=\int_{0}^{\tilde{z}} \phi \mathrm{d} \tilde{z}$, which is coupled to the horizontal velocity-depth profile $\phi$ where $\int_{0}^{1} \phi(\tilde{z}) \mathrm{d} \tilde{z}=1$.

The observed time markers in our study are within the upper two-thirds of the ice thickness, where a constant vertical strain rate is a reasonable assumption. We therefore use a modified column flow (Dansgaard and Johnsen, 1969) that assumes constant horizontal velocity with depth down to a certain height above the bed and from there on linearly decreasing toward the bed. The shape functions can then be expressed for the upper part of the ice thickness (Reeh, 1989):

$$
\phi(\tilde{z})=f \quad \psi(\tilde{z})=1+f(\tilde{z}-1),
$$

where $f$ is the ratio of the surface strain rate to the depthaverage strain rate, and thus determines the shape of the flow functions. Inserting the shape functions (Equation (5)) and the ice flux (Equation (3)) at positions $x_{1}$ and $x_{2}$ in Equation (4), we obtain

$$
\frac{\frac{\alpha_{0} x_{1}^{m+1}}{m+1}+\frac{\alpha_{1} x_{1}^{m+2}}{m+2}+\frac{\alpha_{2} x_{1}^{m+3}}{m+3}+\frac{\alpha_{3} x_{1}^{m+4}}{m+4}}{\frac{\alpha_{0} x_{2}^{m+1}}{m+1}+\frac{\alpha_{1} x_{2}^{m+2}}{m+2}+\frac{\alpha_{2} x_{2}^{m+3}}{m+3}+\frac{\alpha_{3} x_{2}^{m+4}}{m+4}}-(f \tilde{z}+1-f)=0 .
$$

This equation is solved numerically with the input parameters $x_{2}, \alpha_{0}, \ldots, \alpha_{3}, m, f$ and $\tilde{z}$, and gives the original surface position $x_{1}$ of a particle now at $x_{2}$ and the vertical position $\tilde{z}$.

The original surface position $x_{1}$ of a layer (calculated by Equation (6)), is used as input for estimating the deformation of the original layer (taken as the specific surface net balance). The layer thickness $\lambda\left(x_{2}, h_{2}\right)$ is for the part of the ice column where the assumption of constant horizontal velocity with depth is valid (Reeh, 1989),

$$
\frac{\lambda\left(x_{2}, h_{2}\right)}{\lambda\left(x_{2}, H_{2}\right)}=\frac{\dot{b}\left(x_{1}\right)}{\dot{b}\left(x_{2}\right)} \frac{H\left(x_{2}\right)}{H\left(x_{1}\right)}[1+f(\tilde{h}-1)] .
$$

Calculating the layer thickness $\lambda$ over depth at position $x_{2}$ from the surface and down to the transition zone gives the annual-layer thickness-depth profile. As the age at a certain depth equals the number of overlying annual layers, the age-depth profile can be derived by integration over the annual-layer thickness profile.

The depth of isochrones is derived for a given net massbalance pattern along the flowline by computing the agedepth profile in steps down-glacier along the flowline. The horizontal step size should not be larger than the typical ice thickness. The isochrones are then visualized by drawing lines between the point calculations by use of linear interpolation. The optimal net balance pattern that best fits the internal time markers is then found by trial-and-error iteration with different mass-balance forcing.

\section{TEST OF MODEL ASSUMPTIONS}

The assumption of steady state is crucial for this model, and therefore we consider the model sensitivity to variations that could violate this assumption. We have tested the reaction of flowline geometry and the response time, with a non-steadystate flowline model for flowline C on Mýrdalsjökull (Fig. 1).

The response has been estimated for climatic step perturbations of different sizes by solving the continuity equation with a finite-difference numerical scheme (Paterson, 1994; D. MacAyeal, http://homepages.vub.ac.be/ phuybrec/pdf/MacAyeal.lessons.pdf):

$$
\frac{\partial H}{\partial t}+\frac{\partial q}{\partial x}=\dot{b}
$$

where $t$ is time and the ice flux has been taken as $q=H u_{\text {mean }}$. The horizontal (over depth) mean velocity, $u_{\text {mean, }}$ has been expressed (Paterson, 1994):

$$
u_{\text {mean }}=\frac{2 A}{n+2}(\rho g)^{n} H^{n+1}\left(\frac{\partial s}{\partial x}\right)^{n} \text {. }
$$

In the equation, $A$ is a constant and $n$ the exponent in Glen's flow law, $\rho$ is the density of ice, $g$ the gravitation, $s$ the surface elevation and $x$ the distance along the flowline. The scheme was run with a specific balance to develop a flowline reasonably close to the present state. The 


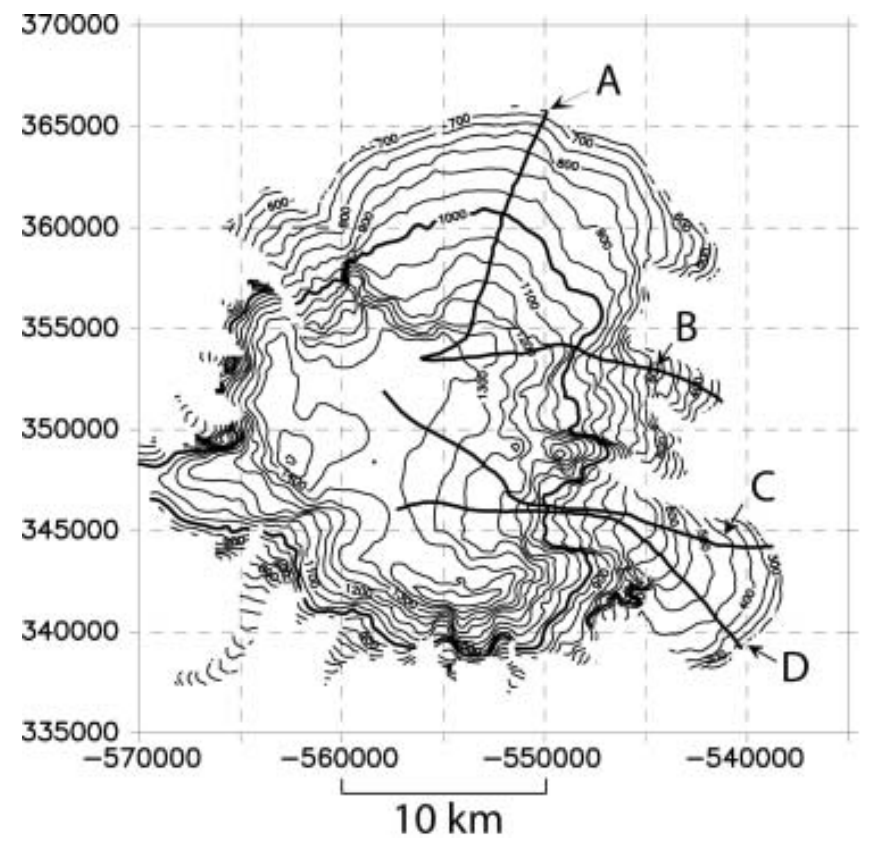

Fig. 1. Map showing Mýrdalsjökull and the location of the flowlines.

flowline was then disturbed with various stepwise massbalance perturbations, giving an estimate of geometrical changes that may be expected within certain time frames. The response time was taken as the time to reach $(1-1 / \mathrm{e}) \approx 2 / 3$ of the volume change from the original state to the new steady-state volume. The selected massbalance perturbations were similar to those estimated during the last century on Vatnajökull ice cap (Schelander, 2000). The response time was calculated as $75 \pm 10$ years which is in good agreement with the timescale $t_{\mathrm{r}}=H_{\max } / \dot{b}$ Jóhannesson and others, 1989; Paterson, 1994). The response time is almost independent of the perturbations (up to $0.6 \mathrm{ma}^{-1}$ step change), which suggest that the massbalance feedback due to a change in elevation is not important for the study area.

The model predicts an elevation change of $\pm 15 \mathrm{~m}$ within the area of the glacier where the flow model has been applied (Fig. 2). With the present-day net balance $\left(3.5-4.5 \mathrm{~m} \mathrm{a}^{-1}\right)$, this elevation change would not significantly change the annual-layer thickness profile. However, the elevation change and velocity pattern are increasing when approaching the equilibrium line, and the model predictions become more questionable.

The model gives some striking differences between the surface topography derived from the continuity equation and the observed surface topography. This is probably a result of the one-dimensionality of the model which does not take into account horizontal convergence and divergence. For the first $8 \mathrm{~km}$, an area with high convergence, the model solution shows a much lower surface than observed. In contrast, the modeled snout predicts a higher surface than observed due to the divergent flow. The difference in ice thickness at the ice divide for a theoretical axisymmetric dome and a non-divergent flowline with the same geometry and ice characteristics was calculated as 0.79 by Van der Veen (1999). That solution is based on several assumptions not fulfilled at Mýrdalsjökull, but gives an approximation of the magnitude that might be attributed to the divergence or convergence. Hence, we

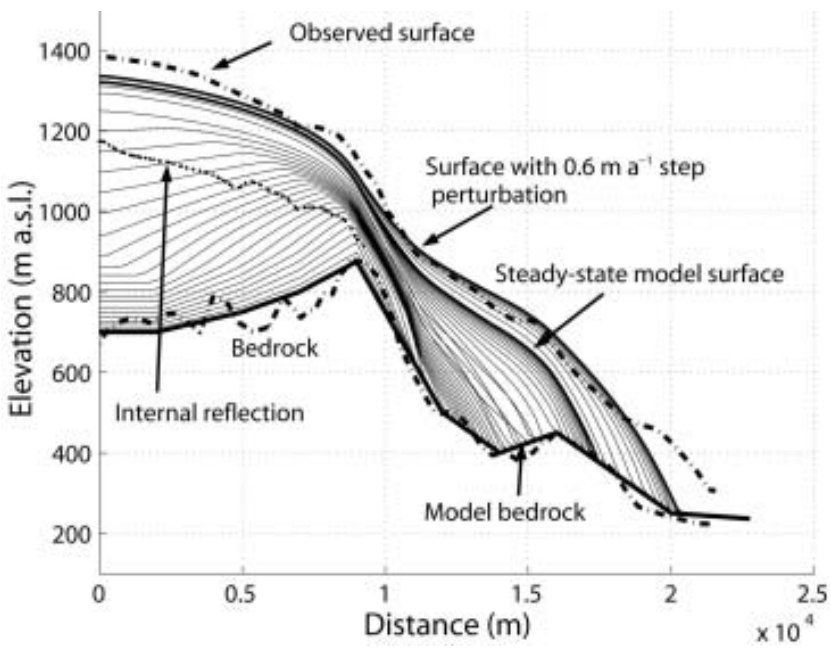

Fig. 2. Cross-section of flowline C, Mýrdalsjökull. The observed bedrock and surface topography is marked with dashed lines, and the internal time marker by dots. The surface elevation change during build-up and after step perturbation is shown by solid lines.

believe the geometric changes, as calculated with the finite-difference scheme with different mass-balance forcing, are reasonable, and thus, that the elevation changes in the study area will be small within the range of perturbations in the mass balance.

In most of the profiles the internal time marker appears slightly higher in the ice column within a distance of one horizontal ice thickness down-glacier from the ice divide. That feature is caused by increased longitudinal stresses at the very dome or ice divide (Raymond, 1983; Reeh, 1988; Reeh and Paterson, 1988; Nereson and others, 2000). The stress field leads to increased vertical velocity in the uppermost layers, but rapidly decreasing with depth, causing the older isochrones to stay closer to the surface. The development of this strain pattern indicates that the ice divide has not migrated significantly since the layers were deposited.

Basal melting due to geothermal activity at the caldera rim of Mýrdalsjökull sometimes creates depressions in the glacier surface and significantly changes the ice-flow pattern (Björnsson, 2002). Figure 3 shows a cross-section of flowline $\mathrm{B}$ where the internal time marker shows a depression $2 \mathrm{~km}$ from the ice divide. Due to bottom melting, the vertical strain rate will be smaller but there will be increased vertical velocity and the layers will appear lower in the ice column within a certain time-span, which might lead to model overestimation of the surface net balance. We have avoided areas where the internal time marker, when topographically mapped over the glacier, shows major local depressions that were not believed to be caused by or connected to bedrock geometry. Areas where surface depressions have been detected (Björnsson and others, 2000) have also been rejected.

The deposition of tephra on the glacier surface affects albedo, but if thick it can insulate the glacier and reduce melting. In the accumulation area the tephra layers will be buried and only affect surface melting over a few years. For the typical mass balances and geometry on Mýrdalsjökull, the Katla 1918 tephra may have changed the depth of the isochrone layer by $7 \pm 4 \mathrm{~m}$ if remaining 5 years on the surface before being buried. 


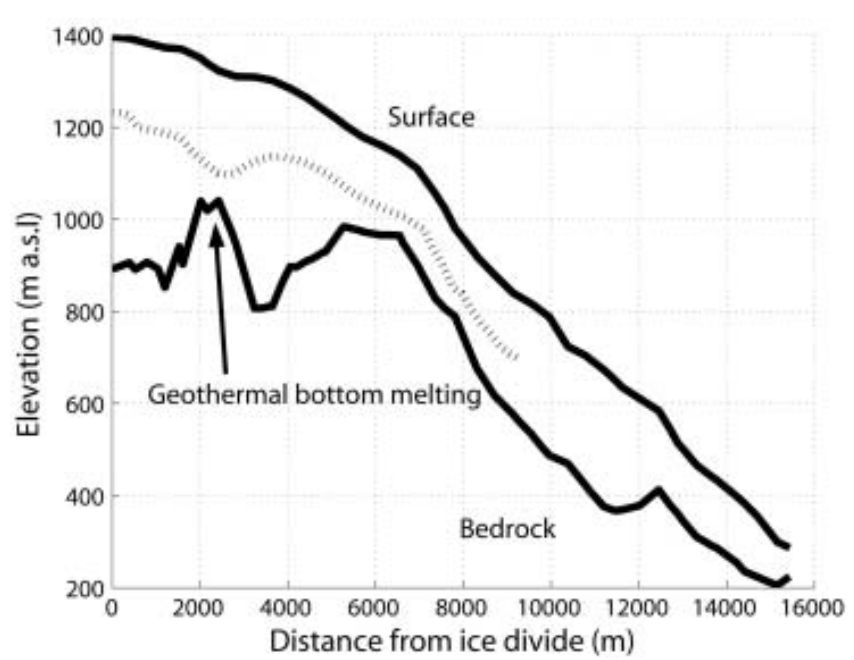

Fig. 3. Cross-section along flowline B. The depression seen in the internal time marker (hatched line) is created by bottom melting at the caldera rim.

\section{AREAS WITH LARGE ICE-THICKNESS GRADIENTS}

The model assumption of a constant shape function $\phi$ along the flowline is questionable for flowlines with large icethickness gradients. Areas with highly varying ice thickness should be avoided. All flowlines investigated in this study show bedrock undulations of the same magnitude as half the ice thickness. The model was tested and compared with icecore data and another flowline model (Reeh, 1988; Reeh and Paterson, 1988). The bedrock has to be smoothed in order to give reasonable results. The smoothing indirectly adjusts the shape function $\phi$ to better fit the real flow pattern in the upper part of the ice column. The most efficient smoothing method was to simply fill in very deep sections where the ice may be assumed relatively stagnant. Figure 4 is reproduced from Reeh and Paterson (1988) and shows the flowline together with our different test bedrocks. Figure 5 shows the annual-layer thickness observed in their ice core, their derived results and our results. The test shows that the assumption of a constant shape function $\phi$ is only valid in the upper part of the ice column when the bedrock has been properly smoothed. However, the comparison with the data from Devon Island, Canada, shows that filling out overdeepenings that are large compared to the ice thickness seems justified.

\section{RESULTS AND ERROR ANALYSIS}

We have computed the balance for three flowlines on Mýrdalsjökull (Fig. 1) and one on Vatnajökull (Fig. 6). The sensitivity of various parameters was predicted by changing one parameter at a time. This shows that smoothing out bedrock irregularities where the ice is thick compared to the overall ice thickness (and hence the assumption of a constant shape function along the flowline) is critical in the model.

\section{Mýrdalsjökull}

The specific net balance pattern required to reconstruct the depth of the tephra layer is different for the various flowlines. Figure 7 shows the flowlines together with the

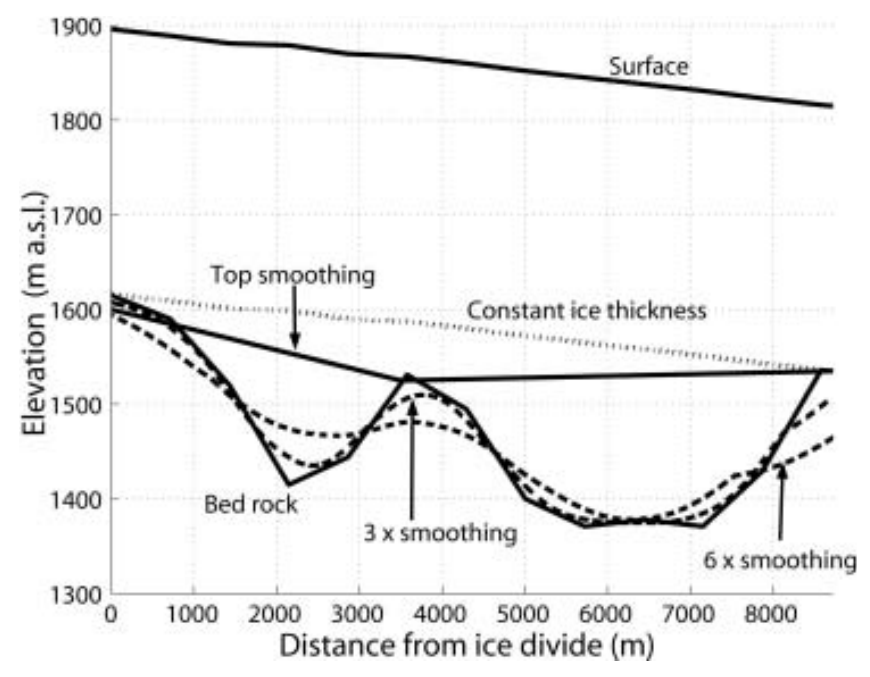

Fig. 4. Cross-section of flowline on Devon Island, Canada, reproduced after Reeh and Paterson (1988). The different bedrocks used as input to the model in this study are added. For discussion of the top smoothing see the text. The number denotes the degree of smoothing relative to the mean ice thickness.

detected internal reflection and the modeled isochrone. The southernmost flowline (D) requires the highest net balance to reproduce an isochrone similar to the internal tephra layer. To reconstruct the internal tephra layer of the northernmost flowline (A) requires the lowest net balance values and the smallest mass-balance gradient with elevation. Flowline $C$ (between flowlines $D$ and $A$ ) shows balance values in between those of the two other flowlines. The computed balances and the expected accuracy are shown in Figure 8 . The balance at the top of flowline D agrees well with an estimate of $4 \mathrm{~m} \mathrm{a}^{-1}$ reported by Sigfúsdóttir (1964) for the nearby dome (1500 ma.s.l) and is further discussed by Sigurðsson and Jónsson (1995). Mackintosh and others (2002) modeled the response of Sólheimajökull (outlet glacier to the south, starting at the dome) and used a reference balance profile representative for the period

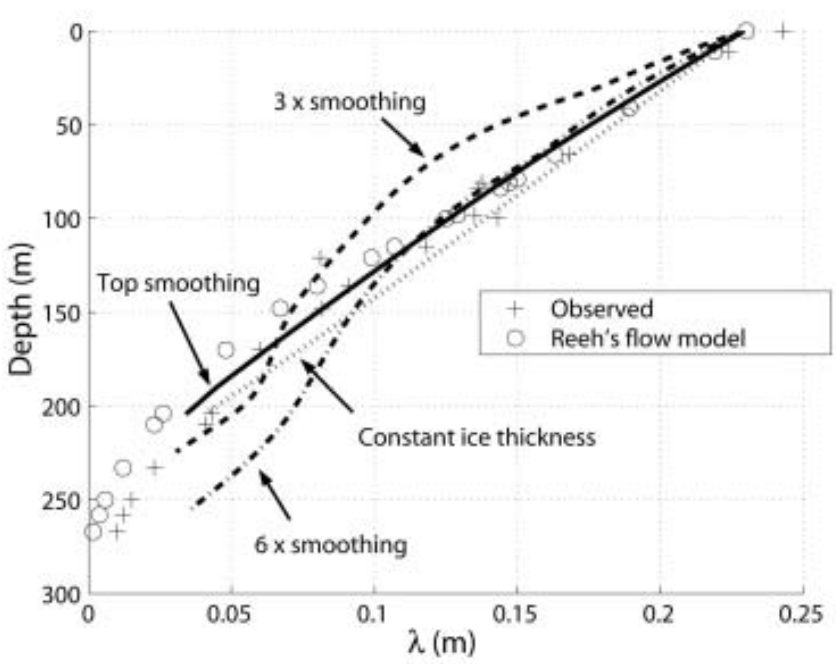

Fig. 5. Annual-layer thickness $(\lambda)$ profile reproduced from Reeh and Paterson (1988) and the annual-layer thickness profiles derived in this paper with different bedrock smoothing. 


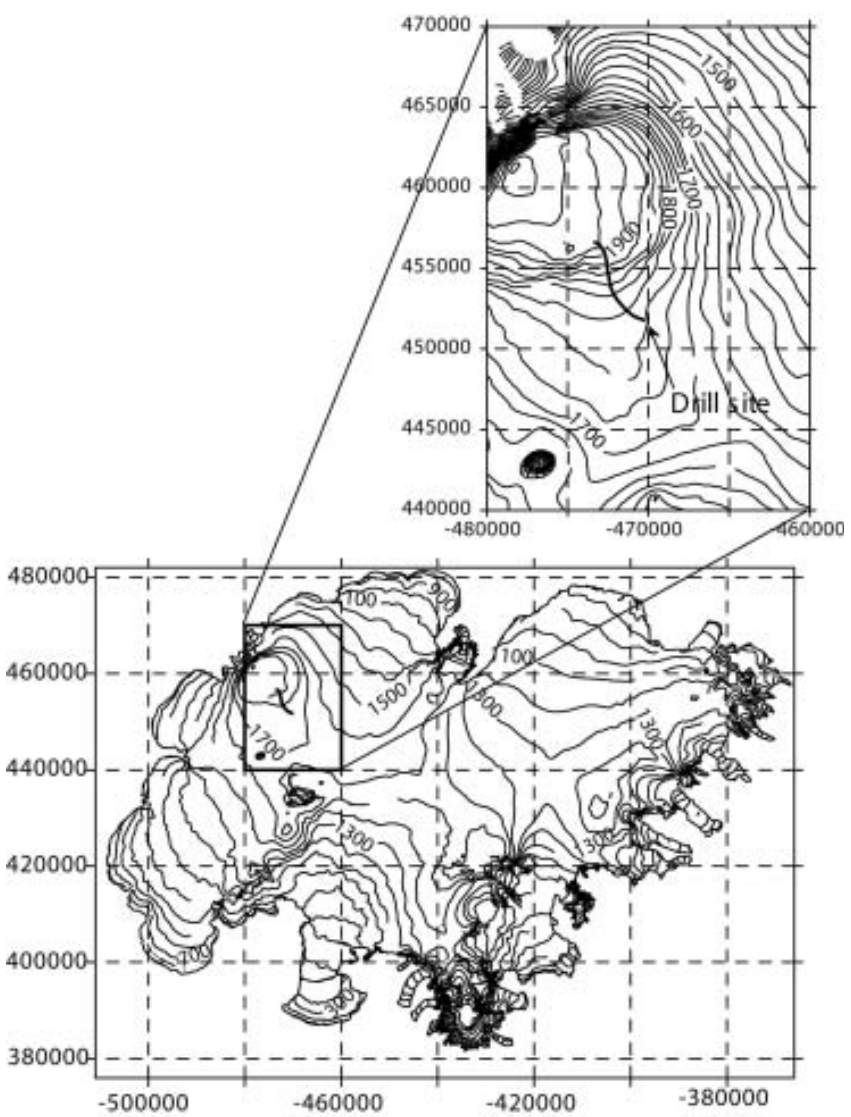

Fig. 6. Map showing Vatnajökull and flowline leading down to the 1972 drill site. Scale in meters.

1961-90 with a balance of $\sim 4 \mathrm{ma}^{-1}$ at $1500 \mathrm{~m}$ a.s.l and $10 \mathrm{~m}$ of ice melt at $100 \mathrm{~m}$ a.s.l.

\section{Error analysis}

The estimates of mass balances are subject to various errors. Shifting the smoothed bedrock up and down within the profiles on Mýrdalsjökull could lead to a change in net balance of $\pm 0.5 \mathrm{~m} \mathrm{a}^{-1}$ in the lower part of the profiles and $\pm 0.3 \mathrm{~m} \mathrm{a}^{-1}$ closer to the ice divide.

Errors in surface, bedrock and internal reflection depths can be caused by digitations, radar precision and positioning problems. The relative accuracy of the depths is considered to be $\pm 10 \mathrm{~m}$. This is in the same order of magnitude as the depth difference that could be attributed to uncertainty as to when the tephra layer actually was covered $(7 \pm 4 \mathrm{~m})$.

Different net balance patterns were tested along the flowlines to test their sensitivity to the depth of the isochrones. Close to the ice divide, a perturbation of $\pm 0.3 \mathrm{~m} \mathrm{a}^{-1}$ can produce a $10 \mathrm{~m}$ vertical displacement of isochrones, while a forcing of $\pm 0.6 \mathrm{~m} \mathrm{a}^{-1}$ would be required close to the equilibrium line.

For the calculations, the depth of the firn layer and the density profile down to the tephra layer must be known. The choice of density-depth profile may produce inaccuracy. All calculations are done in ice equivalent and are afterwards recalculated to water equivalent, using a snow density of $400 \mathrm{~kg} \mathrm{~m}^{-3}$ and an ice density of $900 \mathrm{~kg} \mathrm{~m}^{-3}$. The depth down to a reflector must therefore be recalculated to ice equivalent depth before the model can be applied. The depth and the density profiles change spatially, but we
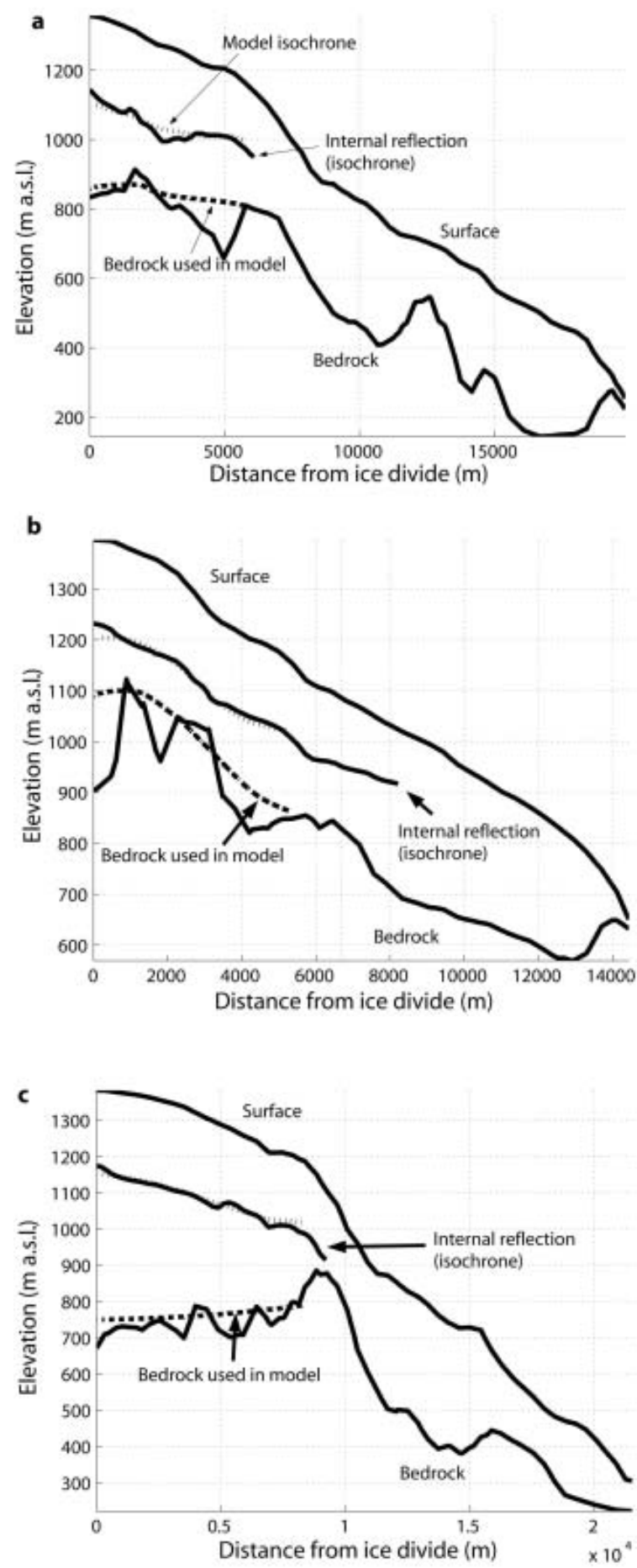

Fig. 7. Cross-sections of flowlines D (a), A (b) and C (c). The surface, bedrock and internal reflection are shown by solid lines, while the model bedrock and model isochrone are shown by stippled lines.

believe the depth correction should be within $\pm 5 \mathrm{~m}$, which is slightly smaller than the accuracy in the depth positioning by the radar.

\section{Vatnajökull}

On Vatnajökull we investigate a flowline leading down to a $400 \mathrm{~m}$ deep drill core of 1972 . The ice core recovered was dated by tephra stratigraphy (Steinthórsson, 1978) by analyzing the chemical characteristics of the detected tephra layers, together with historical records of eruptions and 


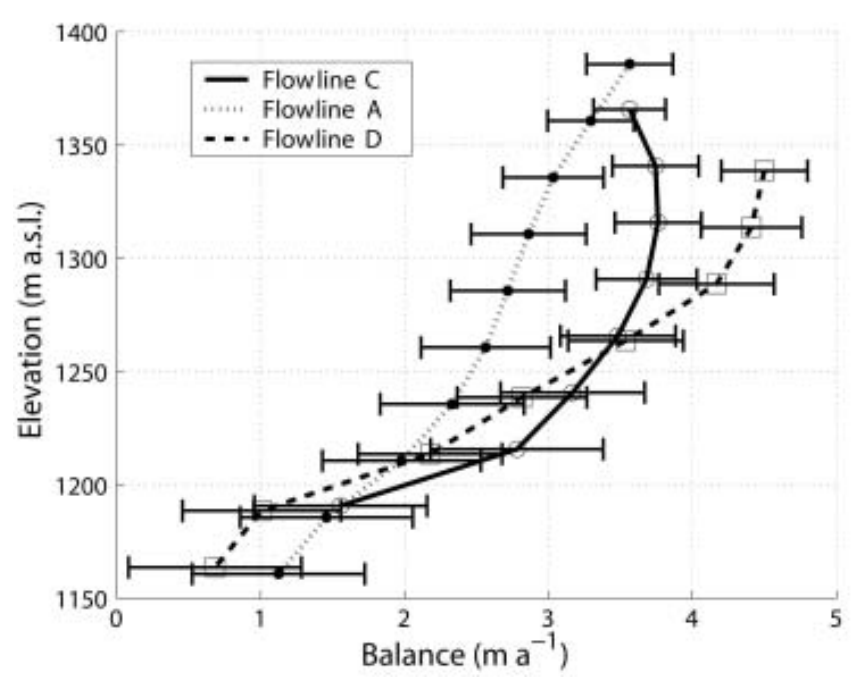

Fig. 8. The balance (water equivalent) as a function of elevation for flowlines A, C and D on Mýrdalsjökull. For discussion of error bars see the text.

fitting the data to a logarithmic timescale (Nye, 1963). The ice thickness was assumed to be $\sim 500 \mathrm{~m}$ during the dating but was later measured by radio echo as being $710 \mathrm{~m}$ (Björnsson, 1988).

We suggest a revised age-depth scale based on running the model with present balance measurements from stakes (Björnsson and others, 1998), known upstream bedrock topography including the effect of divergence and matching the age-depth scale within the upper $120 \mathrm{~m}$ (where the deformation of layers has been comparably small and the age is known from 1918 tephra of Katla in Mýrdalsjökull). The model agrees reasonably well with the original dating of the uppermost $200 \mathrm{~m}$ of the core, but at lower depths their divergence increases (Steinthórsson, 1978). The revised timescale shows good agreement with the distance between dust layers, interpreted as annual layers in the lower part of the core (unpublished data of the Science Institute, University of Iceland). A lower vertical strain rate and thus thicker annual layers cause the age difference. The predicted timescale at the bottom of the core is about 90 years younger than suggested by the previous model. Figure 9 shows the age-depth scale (solid black line) compared with the dating of Steinthórsson (1978).

The various uncertainties, similar to those discussed above for Mýrdalsjökull, may cause dating errors of \pm 10 years. The stippled lines in Figure 9 indicate the sensitivity to mass-balance forcing variations of $0.25 \mathrm{~m} \mathrm{a}^{-1}$ $( \pm 12 \%)$. The firn depth-density correction is assumed to be the same as on Mýrdalsjökull and may describe the difference of the first age mark (tephra layer) but will be insignificant in the lower part. Based on the Mýrdalsjökull experiment, we believe the geometrical changes (mainly elevation changes) caused by a mass-balance perturbation are rather small compared to changes that might have taken place by changed geothermal activity in the vicinity of the Báradarbunga ice dome. However, by changing the geometrical characteristics of the flowline (changing the ice thickness in different ways, and the degree of divergence) the sensitivity of the age-depth scale was tested. A change in divergence from $m=0.3$ to $m=0$ gives 10 years younger

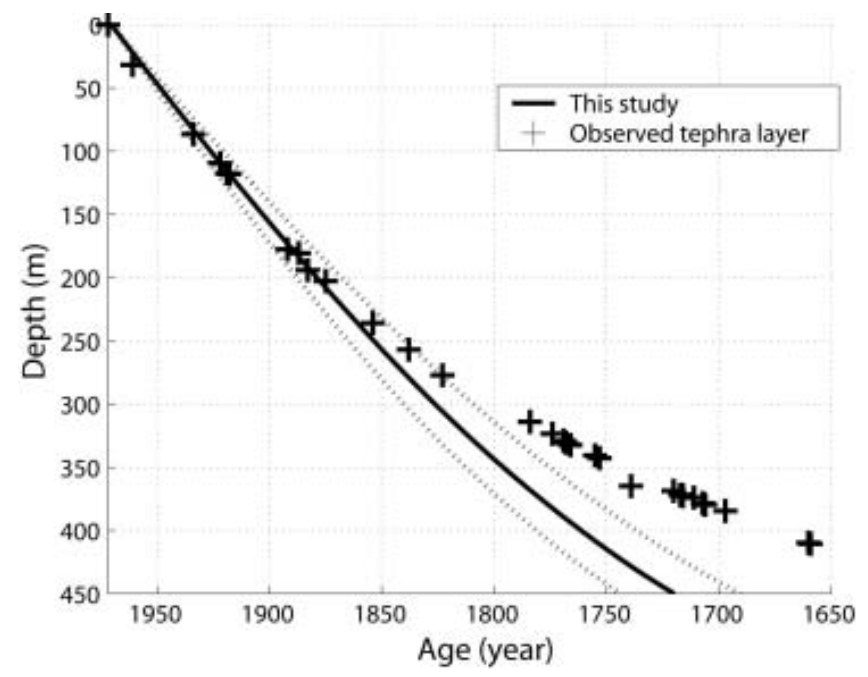

Fig. 9. Suggested age-depth profile for the core drilled in 1972 at Bárdarbunga and the original depth scale of Steinthórsson (1976). Stippled lines show the age-depth change caused by a $\pm 0.25 \mathrm{ma}^{-1}$ mean mass-balance forcing.

ice at $400 \mathrm{~m}$ depth. Lifting the smoothed bedrock $50 \mathrm{~m}$ predicts 5 years older ice at $400 \mathrm{~m}$ depth. These tests do not describe how the age-depth scale would be altered under a shift in geothermal activity, but might justify the flowline not being sensitive to its current geometry. We therefore conclude that the mass-balance forcing is the most sensitive parameter in this flowline.

\section{DISCUSSION}

The model is a useful tool for determining mean specific net balance in the accumulation zone of large ice caps where the bedrock undulations are small compared to the ice thickness. The model fails close to the bedrock and in areas with rough bedrock topography (undulations of the order of half a mean ice thickness) and should not be applied close to ice divides and in areas with high longitudinal stresses, because of violation of the assumption of constant shape function $\phi$ (the horizontal velocity profile over depth). The model is highly sensitive to strong ice-thickness variations so that smoothing of bedrock undulations is required. The model should not be applied in areas with high bottom melting. Close to the equilibrium line, a change in mass balance will produce a large change in elevation and velocities, and thus the steady-state assumption is violated.

\section{CONCLUSIONS}

Internal tephra layers of known age provide useful information on glacier specific net balance rates. Studies of three flowlines on Mýrdalsjökull indicate a higher specific net balance in the southern part of the ice cap, $\left(4.5 \mathrm{~m} \mathrm{a}^{-1}\right.$ w.e. vs $3.5 \mathrm{~m} \mathrm{a}^{-1}$ in the north at $1350 \mathrm{~m}$ a.s.l.).

The response time for perturbations in a climatic massbalance forcing is $75 \pm 10$ years for a selected flowline on Mýrdalsjökull. The response time is not sensitive to step perturbations smaller than $0.6 \mathrm{~m} \mathrm{a}^{-1}$.

A revised model for the age-depth relationship of the $400 \mathrm{~m}$ deep 1972 ice core recovered from the Bárdarbunga 
dome suggests that the lower part (below $250 \mathrm{~m}$ ) is younger than previously reported. The lowermost part of the core $(411 \mathrm{~m})$ is estimated to have been deposited in $\sim \mathrm{AD} 1753$ instead of $\mathrm{AD} 1659$, a difference of 94 years.

\section{ACKNOWLEDGEMENTS}

This work was supported by the University of Iceland Research Fund. N. Reeh has been highly involved in the work and we thank him for his patience and time. We also thank $H$. Oerlemans and an anonymous reviewer for substantially improving the paper.

\section{REFERENCES}

Baldwin, D.J., J.L. Bamber, A.J. Payne and R.L. Layberry. 2003. Using internal layers from the Greenland ice sheet, identified from radio-echo sounding data, with numerical models. Ann. Glaciol., 37, 325-330.

Björnsson, H. 1980. Glaciers in Iceland. Jökull, 29, 74-80.

Björnsson, H. 1988. Hydrology of ice caps in volcanic regions. Vísindafélag Ísl. Rit 45.

Björnsson, H. 2002. Subglacial lakes and jökulhlaups in Iceland. Global Planet. Change, 35(3-4), 255-271.

Björnsson, H., F. Pálsson, M.T. Guðmundsson and H.H. Haraldsson. 1998. Mass balance of western and northern Vatnajökull, Iceland, 1991-1995. Jökull, 45, 35-58.

Björnsson, H., F. Pálsson and M.T. Guðmundsson. 2000. Surface and bedrock topography of Mýrdalsjökull, Iceland: the Katla caldera, eruption sites and routes of jökulhlaups. Jökull, 49, 29-46.

Brandt, O. 2001. Past specific net balance rates of the Mýrdalsjökull and Vatanjökull ice caps, Iceland, derived by dating internal tephra layers on the basis of ice dynamics: model and sensitivity analysis. (Cand. Scient. thesis, University of Bergen and University of Iceland.)

Dansgaard, W. and S.J. Johnsen. 1969. A flow model and a time scale for the ice core from Camp Century, Greenland. J. Glaciol., 8(53), 215-223.

Eythórsson, J. and H. Sigtryggsson. 1971. The climate and weather of Iceland. In Tuxen, S.L., ed. Zoology of Iceland. Vol. 1, Part 3. Copenhagen/Reykjavík, Ejnar Munksgaard.

Hammer, C.U., H.B. Clausen, W. Dansgaard, N. Gundestrup, S.J. Johnsen and N. Reeh. 1978. Dating of Greenland ice cores by flow models, isotopes, volcanic debris, and continental dust. J. Glaciol., 20(82), 3-26.

Jóhannesson, T. and O. Sigurðsson. 1998. Interpretation of glacier variations in Iceland 1930-1995. Jökull, 45, 27-33.

Jóhannesson, T., C. Raymond and E. Waddington. 1989. Time-scale for adjustment of glaciers to changes in mass balance. J. Glaciol., 35(121), 355-369.
Karlöf, L. and 13 others. 2000. A 1500 year record of accumulation at Amundsenisen, western Dronning Maud Land, Antarctica, derived from electrical and radioactive measurements on a $120 \mathrm{~m}$ ice core. J. Geophys. Res., 105(D10), $12,471-12,483$

Larsen, G., M.T. Gudmundsson and H. Björnsson. 1996. Tephrastratigraphy of ablation areas of Vatnajökull ice cap, Iceland. CRREL Spec. Rep. 96-27, 75-80.

Larsen, G., M.T. Gudmundsson and H. Björnsson. 1998. Eight centuries of periodic volcanism at the center of the Iceland hot spot revealed by glacier tephrastratigraphy. Geology [Boulder], 26(10), 943-946.

Mackintosh, A.D., A.J. Dugmore and A.L. Hubbard. 2002. Holocene climatic changes in Iceland: evidence from modelling glacier length fluctuations at Sólheimajökull. Quat. Int., 91(1), 39-52.

Nereson, N.A., C.F. Raymond, R.W. Jacobel and E.D. Waddington. 2000. The accumulation pattern across Siple Dome, West Antarctica, inferred from radar-detected internal layers. J. Glaciol., 46(152), 75-87.

Nye, J.F. 1963. Correction factor for accumulation measured by the thickness of the annual layers in an ice sheet. J. Glaciol., 4(36), 785-788.

Paterson, W.S.B. 1994. The physics of glaciers. Third edition. Oxford, etc., Elsevier.

Raymond, C.F. 1983. Deformation in the vicinity of ice divides. J. Glaciol., 29(103), 357-373.

Reeh, N. 1988. A flow-line model for calculating the surface profile and the velocity, strain-rate, and stress fields in an ice sheet. J. Glaciol., 34(116), 46-54.

Reeh, N. 1989. The age-depth profile in the upper part of a steadystate ice sheet. J. Glaciol., 35(121), 406-417.

Reeh, N. and W.S.B. Paterson. 1988. Application of a flow model to the ice-divide region of Devon Island Ice Cap, Canada. J. Glaciol., 34(116), 55-63.

Schelander, P. 2000. Reconstruction of mass balance on Vatnajökull, Iceland, using a classification of large-scale circulation. (Cand. Scient. thesis, University of Bergen.)

Sigfúsdóttir, A.B. 1964. Nedbör og temperatur i Island. In Islands hydrologi. Reykjavík, Raforkumálastjóri, 1I2-1-1I2-17. (Nordiske Hydrologkonferanse 4.)

Sigurðsson, O. 1998. Glacier variations in Iceland 1930-1995: from the database of the Iceland Glaciological Society. Jökull, 45, 3-25.

Sigurðsson, O. and T. Jónsson. 1995. Relation of glacier variations to climate changes in Iceland. Ann. Glaciol., 21, 263-270.

Steinthórsson, S. 1978. Tephra layers in a drill core from the Vatnajökull ice cap. Jökull, 27, 2-27.

Thorsteinsson, T., O. Sigurðsson, G. Larsen and F. Wilhelms. 2002. Ice core drilling on the Hofsjökull ice cap. Jökull, 51, 25-41.

Van der Veen, C.J. 1999. Fundamentals of glacier dynamics. Rotterdam, etc., A.A. Balkema. 